\title{
FIRES FOLLOWING BARK BEETLES: FACTORS CONTROLLING SEVERITY AND DISTURBANCE INTERACTIONS IN PONDEROSA PINE
}

\author{
Carolyn H. Sieg1*, Rodman R. Linn², Francois Pimont ${ }^{3}$, Chad M. Hoffman ${ }^{4}$, \\ Joel D. McMillin ${ }^{5}$,Judith Winterkamp ${ }^{2}$, and L. Scott Baggett ${ }^{6}$ \\ ${ }^{1}$ USDA Forest Service, Rocky Mountain Research Station, \\ 2500 Pine Knoll Drive, Flagstaff, Arizona 86001, USA \\ ${ }^{2}$ Earth and Environmental Sciences Division, Los Alamos National Laboratory, \\ Mail Stop T003, Los Alamos, New Mexico 87544, USA \\ ${ }^{3}$ INRA-UR629, Ecologie des Forêts Méditerranéennes (URFM), Site Agroparc, \\ Domaine Saint Paul, F-84914 Avignon, France \\ ${ }^{4}$ Department of Forest and Rangeland Stewardship, Colorado State University, \\ 1472 Campus Delivery Fort Collins, Colorado 80523, USA \\ ${ }^{5}$ USDA Forest Service, Forest Health Protection, \\ 1249 South Vinnell Way, Suite 200, Boise, Idaho 83709, USA \\ ${ }^{6}$ USDA Forest Service, Rocky Mountain Research Station, \\ 240 Prospect Street, Fort Collins, Colorado 80526, USA \\ *Corresponding author: Tel.: +1-928-556-2151; e-mail: csieg@fs.fed.us
}

\begin{abstract}
Previous studies have suggested that bark beetles and fires can be interacting disturbances, whereby bark beetlecaused tree mortality can alter the risk and severity of subsequent wildland fires. However, there remains considerable uncertainty around the type and magnitude of the interaction between fires following bark beetle attacks, especially in drier forest types such as those dominated by ponderosa pine (Pinus ponderosa Lawson \& C. Lawson). We used a full factorial design across a range of factors thought to control bark beetle-fire interactions, including the temporal phase of the
\end{abstract}

\section{RESUMEN}

Estudios previos han sugerido que los escarabajos de la corteza y el fuego pueden ser disturbios interactivos, por lo que la mortalidad de árboles causada por estos escarabajos puede alterar el riesgo y la severidad de incendios subsecuentes. Sin embargo, una considerable incertidumbre persiste en torno al tipo y magnitud de la interacción entre los incendios que siguen al ataque de insectos, especialmente en tipos de bosques secos como los dominados por pino ponderosa (Pinus ponderosa Lawson \& C. Lawson). Usamos un diseño factorial a través de un rango de factores que pensamos controlaban la interacción entre el escarabajo de la corteza y los incendios, incluyendo la fase temporal del estallido del insecto, el nivel 
outbreak, level of mortality, and wind speed. We used a three-dimensional physics-based model, HIGRAD/FIRETEC, to simulate fire behavior in fuel beds representative of 60 field plots across five national forests in northern Arizona, USA. The plots were dominated by ponderosa pine, and encompassed a gradient of bark beetlecaused mortality due to a mixture of both Ips and Dendroctonus species. Non-host species included two sprouting species, Gambel oak (Quercus gambelii Nutt.) and alligator juniper (Juniperus deppeana Steud.), as well as other junipers and pinyon pine ( $\mathrm{Pi}$ nus edulis Engelm.). The simulations explicitly accounted for the modifications of fuel mass and moisture distribution caused by bark beetle-caused mortality. We first analyzed the influence of the outbreak phase, level of mortality, and wind speed on the severity of a subsequent fire, expressed as a function of live and dead canopy fuel consumption. We then computed a metric based on canopy fuel loss to characterize whether bark beetles and fire are linked disturbances and, if they are, if the linkage is antagonistic (net bark beetle and fire severity being less than if the two disturbances occurred independently) or synergistic (greater combined effects than independent disturbances). Both the severity of a subsequent fire and whether bark beetles and fire are linked disturbances depended on the outbreak phase of the bark beetle mortality and attack severity, as well as the fire weather (here, wind). Greater fire severity and synergistic interactions were generally associated with the "red phase" (when dead needles remain on trees). In contrast, during the "gray phase" (when dead needles had fallen to the ground), fire de mortalidad y la velocidad del viento. Para simular el comportamiento del fuego en camas de combustible en 60 parcelas representativas a lo largo de cinco bosques nacionales en el norte de Arizona, EEUU, usamos el modelo físico tridimensional HIGRAD/FIERETEC. Las parcelas estaban dominadas por pino ponderosa, y abarcaban un gradiente de mortalidad causado por escarabajos de diversas especies, tanto de los géneros Ips como de Dendroctonus. Las especies no hospedantes de estos escarabajos incluían a dos rebrotantes como el roble de Gambela (Quercus gambelii Nutt.) y el táscate (Juniperus deppeana Steud.), como así también otras especies de juníperos y de pino edulis (Pinus edulis Engelm.). Las simulaciones representaron explícitamente las modificaciones de la biomasa combustible y la distribución de humedad causada por la mortalidad inducida por estos escarabajos. Primeramente analizamos la influencia de la fase del estallido poblacional, el nivel de mortalidad, y la velocidad del viento, en la severidad de un incendio subsecuente, expresado en función del consumo de combustible vivo y muerto del dosel. Luego computamos una medida basada en la pérdida del combustible del dosel para caracterizar si los escarabajos de la corteza y el fuego son disturbios relacionados entre sí y, si lo son, si esa relación es antagónica (daño por el escarabajo y severidad del fuego son menores que cuando ambos disturbios ocurren independientemente), o sinérgica (mayores efectos combinados que si ocurriesen independientemente). Ambos, la severidad de un incendio subsecuente y si los escarabajos y el fuego son disturbios relacionados, dependen de la fase del estallido, de la mortalidad, y de la severidad del ataque, y también del entorno meteorológico del fuego, en este caso la velocidad del viento. Una mayor severidad e interacciones sinérgicas fueron generalmente asociadas con la fase "roja" (cuando las acículas muertas permanecen en los árboles). En contraste con esto, durante la fase "gris" (cuando las acículas han caído al suelo), 
severity was either similar to, or less than, green-phase fires and interactions were generally antagonistic, but included both synergistic and neutral interactions. The simulations also revealed that the magnitude of the linkage between these two disturbances was smaller for fires occurring during high wind conditions, especially in the red phase. This complexity might be a reason for the contrasted or controversial perception of bark beetle-fire interactions reported in the literature, since both fire severity and the type and magnitude of the linkage can vary strongly among studies. These results suggest that, for fires burning in the gray phase following moderate levels of mortality, bark beetle-caused mortality may buffer rather than exacerbate fire severity. However, for fires burning under high wind speeds, regardless of the outbreak phase or level of mortality, the near complete loss of canopy fuels may push this ecosystem into an alternative state dominated by sprouting species. la severidad del fuego fue similar a, o menor que, las fases de fuego "verde" y las interacciones fueron generalmente antagónicas, pero incluyeron también interacciones sinérgicas y neutras. Las simulaciones también revelaron que la magnitud entre ambos disturbios fue menor durante la ocurrencia de vientos fuertes, especialmente en la fase roja. Esta complejidad podría ser una razón sobre la percepción controversial o contrastante de las interacciones entre estos escarabajos y el fuego reportados en la literatura, dado que ambos, la severidad y el tipo y magnitud de la relación, pueden variar fuertemente entre estudios. Estos resultados sugieren que, para incendios que queman en la fase gris seguidos de moderados niveles de mortalidad, la causa de mortalidad debida a los escarabajos puede atemperar, más que exacerbar, la severidad del fuego. Sin embargo, para incendios que queman bajo fuertes velocidades de viento, independientemente de la fase del estallido o el nivel de mortalidad, el casi completo consumo del dosel puede derivar este ecosistema a un estado alternativo dominado por especies rebrotantes.

Keywords: antagonism, canopy fuel consumption, Dendroctonus, fire severity, HIGRAD/FIRETEC, interacting disturbances, Ips, linked disturbances, Pinus ponderosa, synergism

Citation: Sieg, C.H., R.R. Linn, F. Pimont, C.M. Hoffman, J.D. McMillin, J. Winterkamp, and L.S. Baggett. 2017. Fires following bark beetles: factors controlling severity and disturbance interactions in ponderosa pine. Fire Ecology 13(3): 1-23. doi: 10.4996/fireecology.130300123

\section{INTRODUCTION}

Natural disturbances can have complex and sometimes unpredictable effects on ecosystems by changing their susceptibility to and severity of subsequent disturbances (Darling and Côté 2008, Metz et al. 2013). Recent droughts and favorable host conditions throughout western North America have led to widespread tree mortality due to bark beetles (Curculionidae: Scolytinae), raising concerns that high levels of tree mortality could trigger severe wildfires (Bentz et al. 2009). Ultimately, a major concern is that the interaction of the two disturbances reduces resiliency or pushes the ecosystem into an alternative state that is otherwise unlikely in the absence of the interaction (Gunderson et al. 2000). However, both the severity of a fire following bark beetle-caused mortality and the type and magnitude of bark beetle-wildfire interactions may depend upon a number of factors. These factors include the temporal phase of the outbreak, severity and rate of the mortality, the 
species-specific beetle-host combination, and the fire weather (see reviews in Jenkins et al. 2008, 2012, 2014; Hicke et al. 2012). How bark beetle-caused mortality alters the severity of a subsequent fire as well as the type and magnitude of the interaction between fires following bark beetle-caused mortality remains poorly understood across the gradient of these controlling factors, especially in dry forest types such as those dominated by ponderosa pine (Pinus ponderosa Lawson \& C. Lawson).

Although many studies have made inferences regarding the nature of bark beetle-fire interactions based on changes in fire severity, relatively few have directly assessed if these changes are due to an interaction between the two disturbances. The nature of the interaction between two disturbances is classified as either neutral or linked depending upon the combined impact of the two disturbances relative to the sum of the effects of the independent disturbances. If bark beetles and fire are linked disturbances, the linkage can be either synergistic, in which the combined severity is greater than the total severity of the two disturbances occurring independently, or antagonistic, in which the combined disturbance severity is lower than the severity if the disturbances occurred independently (Turner and Bratton 1987). If we define severity as the combined loss of canopy foliar mass due to the disturbances, then a synergistic bark beetle-fire interaction would result in greater foliar mass loss relative to the sum of independent bark beetle outbreaks and wildfires. In contrast, an antagonistic bark beetle-fire interaction would result in a net mass loss relative to the sum of the two disturbances occurring independently. Alternatively, if the two disturbances are not linked, they are considered neutral (also called additive), as mass loss of the combined disturbances is similar to the mass loss of the disturbances occurring independently (Turner and Bratton 1987).

Due to the difficulties in assessing disturbance interactions relative to the two distur- bances occurring independently, most studies have inferred interactions based on comparisons of fire severity following bark beetle mortality relative to fire severity without bark beetles present. These previous studies have provided insights into some of the controlling factors on fire behavior in bark beetle-impacted fuels, foremost of which is the temporal phase of the outbreak. Many studies have categorized the time between the occurrence of the bark beetle outbreak and a wildland fire into distinct temporal phases that represent the major changes in the forest fuel complex following the outbreak (e.g., Hicke et al. 2012). The temporal sequence of interest in this paper begins with the green phase (unattacked), and progresses through red (red needles remain on dead trees), and then to the gray phase (dead needles have fallen to the ground). Previous studies have suggested that bark beetle-caused mortality influences the canopy fuel moisture in the red phase and canopy fuel continuity in the gray phase thus affecting the severity of a subsequent fire. Theoretical frameworks and some studies predict higher fire severity in the red phase and lower in the gray phase (Jenkins et al. 2008, Hicke et al. 2012, Prichard and Kennedy 2014, Meigs et al. 2016). However, other studies have suggested that fires during the gray phase may be more severe than fires in green-phase forests, or they may be less severe or have little effect on fire severity in either phase (Hoffman 2011; Simard et al. 2011; Donato et al. 2013; Harvey et al. 2014a, 2014b). These varying fuel effects across the temporal phases thus can potentially alter both the severity of a subsequent fire as well as type and magnitude of the bark beetle-fire interaction.

The lack of consistency is in part due to the effect of other controlling factors, including the severity and rate of bark beetle-caused mortality, specific bark beetle-host combinations, and fire weather. For example, several studies have suggested that the severity and rate of bark beetle-caused mortality plays a pivotal role in the severity of a subsequent fire (DeRose and 
Long 2009; Hoffman et al. 2012b; Donato et al. 2013; Harvey et al. 2014a, 2014b; Hoffman et al. 2015). Thus, varying levels and rates of mortality may alter subsequent fire severity, whether the disturbances are linked or not, and even the type and magnitude of the interaction across different phases. Studies have also suggested that the effects of the severity of bark beetle-caused mortality on fire severity can be non-linear, whereby effects occur at some levels but not at others (e.g., DeRose and Long 2009, Hoffman 2011). Further, the effect of bark beetle-caused mortality severity on subsequent fire severity is likely to vary due to differences in pre-outbreak forest structures and beetle selection differences associated with various bark beetle-host combinations (Hicke et al. 2012). Finally, fire weather during a subsequent fire can alter the influence that bark beetle-caused mortality has on fire severity (Harvey et al. 2013, Hart et al. 2015, Andrus et al. 2016), and have the potential to alter both fire severity as well as the type and magnitude of the interaction. For example, high wind speeds can alter the heat transfer processes and decrease the relative effect of small-scale variations in the fuels complex on fire behavior and effects (Linn et al. 2013). However, few studies have explicitly evaluated the nature of bark beetle-fire interactions or the potential influence of other controlling factors.

The aim of this study was to quantify the influence of the temporal phase of the outbreak, level of mortality, and burning conditions on fire severity and to quantify the type and magnitude of the interaction of a fire following bark beetle-caused morality across these gradients. To meet our objective, we utilized field-based data (Hoffman et al. 2012a) to develop analogous mixed-species forests dominated by ponderosa pine that represent the range of tree mortality measured in the field. We then simulated fire behavior using a full factorial design that included a temporal sequence, with three levels of mortality and three open wind speeds using HIGRAD/FIRE-
TEC, a three-dimensional detailed physics-based model. For each simulation, we assessed fire severity by quantifying dead, live, and total canopy fuel consumption. We then quantified the type and magnitude of the interaction, based on live fuel mortality, by adapting the metric of canopy mass loss that Metz et al. (2013) used to explore the interaction between an introduced pathogen and fire. The metric contrasts live canopy fuel loss due to the two disturbances occurring separately to canopy fuel loss due to a fire (foliage consumption) following bark beetle-caused mortality (foliage mortality). We hypothesized: 1) that fire severity (total canopy fuel consumption) would increase in the red phase and decrease in the gray phase, relative to the green phase, with increasing levels of mortality either increasing (red phase) or decreasing (gray phase) consumption. 2) The bark beetle-fire interaction would be synergistic during the red phase and antagonistic during the gray phase, with the magnitude of the interaction increasing with the level of mortality and decreasing with increasing wind speeds, since fine-scale effects of mortality levels would be overwhelmed at high wind speeds.

\section{METHODS \\ HIGRAD/FIRETEC Simulation Fuel Beds Setup}

To meet our overall objectives, we used HIGRAD/FIRETEC (hereafter referred to as FIRETEC), a coupled fire-atmospheric model (Linn 1997, Linn et al. 2002). FIRETEC captures essential physical phenomena that determine the behavior of a wildfire through the solution of a set of coupled partial differential equations that rely on a Large Eddy Simulation (LES) approach (Pimont et al. 2009, Dupuy et al. 2011). Since FIRETEC can account for spatially heterogeneous fuel and fuel moistures with $\sim 2 \mathrm{~m}$ resolution, it has proved useful for exploring the effects of bark beetle- 
caused tree mortality on fire behavior in other forest types (e.g., Linn et al. 2013, Hoffman et al. 2015). Further, the model has produced realistic simulations of historical fires (Bossert et al. 2000, Bradley 2002) and experimental field fires (Linn and Cunningham 2005, Pimont et al. 2009, Dupuy et al. 2011, Linn et al. 2012, Dupuy et al. 2014, Pimont et al. 2014). Most pertinently to this study, FIRETEC has reproduced moisture-sensitivity experimental results (Marino et al. 2012) and produced realistic simulations of canopy field experiments (Linn et al. 2012, Pimont et al. 2014), and crown fire rate-of-spread estimates in bark beetle-impacted fuels (Hoffman et al. 2016).

\section{FIRETEC Simulation Fuel Beds Setup}

We conducted all FIRETEC simulations using a consistent three-dimensional $400 \mathrm{~m} \times$ $400 \mathrm{~m} \times 615 \mathrm{~m}$ grid of computational domain with a horizontal resolution of $2 \mathrm{~m}$ and a vertical resolution that varied from $\sim 1.5$ m near the ground to $\sim 3 \mathrm{~m}$ near the top of the canopy. We derived realistic fuel input for FIRETEC from individual tree data collected in 60 plots of ponderosa pine forests immediately following an abrupt and widespread bark beetle outbreak in 2001 to 2003 in Arizona, USA (Hoffman et al. 2012a). The mixed-species plots were composed of $\sim 71 \%$ ponderosa pine, with Gambel oak (Quercus gambelii Nutt.), several species of junipers (Juniperus spp. L.), pinyon pine (Pinus edulis Engelm.), and Douglas-fir (Pseudotsuga menziesii [Mirb.] Franco) constituting the remaining $30 \%$ of the trees (Table 1). Ponderosa pine mortality occurred across a range of tree diameters due to the multiple species of bark beetles, including Ips (Ips lecontei Swaine and I. pini Say) and Dendroctonus species (D. brevicomis LeConte, D. adjunctus Blandford, and D. frontalis Zimmerman) (USDA Forest Service 2004; Williams et al. 2008). We randomly distributed sampled trees within the computational domain follow- ing Ripley (1977), such that the analogous forest represented the plot-level averages in terms of density, species composition, canopy base height, and tree heights described by Hoffman et al. (2012a; Table 1). We distributed the biomass in each tree using a series of parabolic profiles similar to Linn et al. (2005), in which the tree crown dimensions were determined using a combination of field tree measurements, and an estimated canopy width following Bechtold (2004). Because larger diameter woody crown fuel components $(>2 \mathrm{~mm})$ are considered to contribute little to crown fires (Rothermel 1983), our simulated crowns only consisted of fine fuels $<2 \mathrm{~mm}$, such as needles and small twigs. We represented surface fuel load within the computational domain as a combination of fine dead down woody fuels from Hoffman et al. (2012a) and herbaceous loadings from Sabo et al. (2009). For all simulations, the litter fuel moisture was set at 3\% and herbaceous fine fuel moisture at $30 \%$ to represent a very low dead fuel moisture scenario with mixed live and cured herbaceous layer similar to the D1L1 scenario in BehavePlus (Andrews 2009).

We ran a total of 21 simulations: three green phase to account for fire behavior in no-mortality stands (Figure 1A) at three wind speeds, plus nine red phase and nine gray phase to account for three levels of mortality and three wind speeds (see Table 2 for a summary of stand and fuel characteristics for simulations). To simulate different levels of bark beetle-caused mortality, we randomly selected to "kill" $20 \%, 58 \%$, or all of the ponderosa pine trees in the simulated domain. These percentages represented the observed range and mean amount of mortality, and the random selection of "killed" trees is in agreement with field observations that documented mortality in all tree size classes (Hoffman et al. 2012a). This approach makes a simplifying assumption that the mortality was synchronous; in reality, the mortality occurred over two years (Negrón et al. 2009). We simulated each level 
Table 1. Stand and fuel characteristics in Southwestern mixed-species stands dominated by ponderosa pine (host species) used for the design of fire simulation input. Mortality was attributed to both Ips and Dendroctonus bark beetles. Simulation mortality levels are based on the low, average, and high levels observed in 60 field plots (Hoffman et al. 2012a). DBH = diameter at breast height, HGT = tree height, and $\mathrm{CBH}=$ canopy base height.

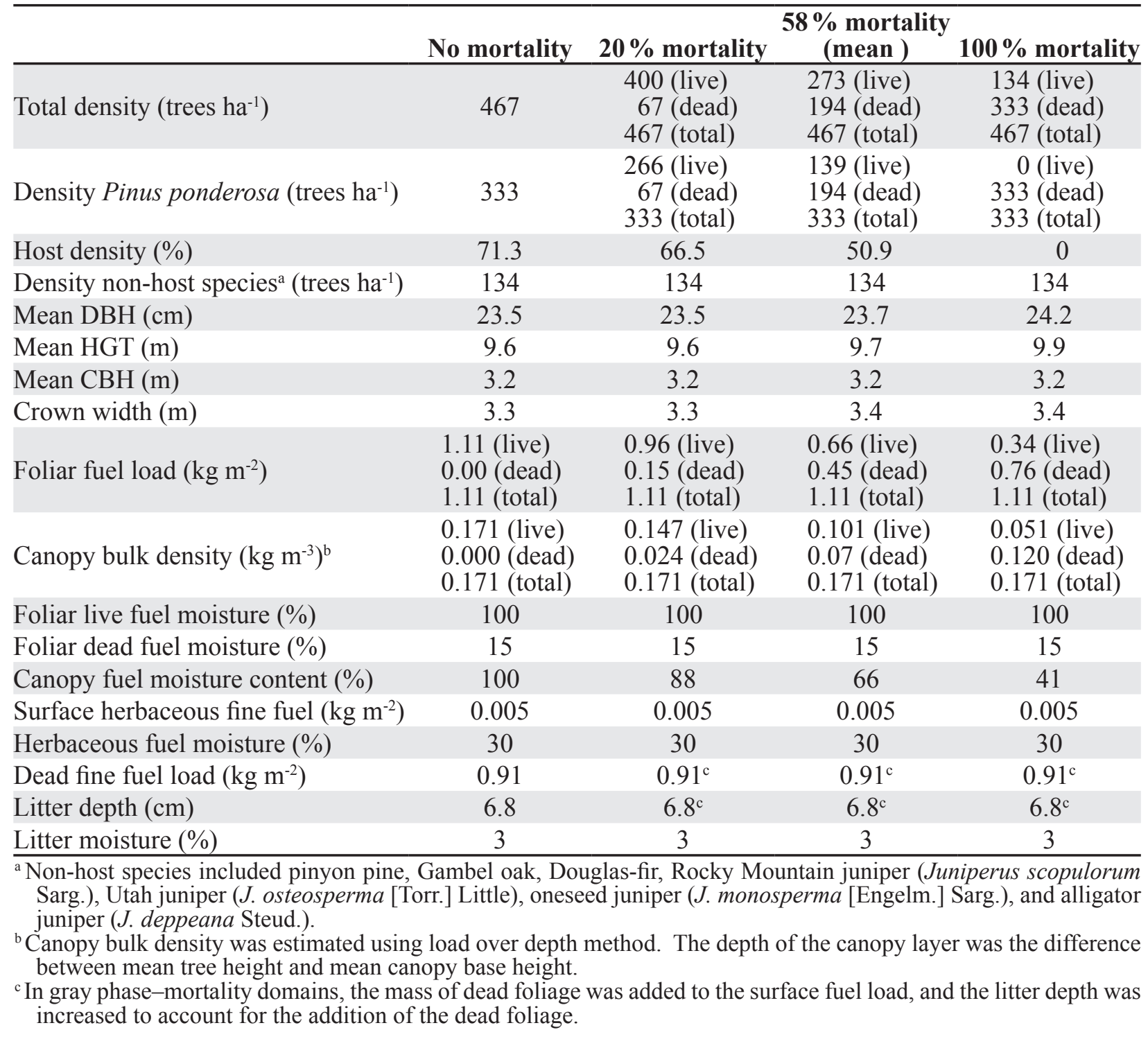

of mortality for both the red and the gray phases, to account for temporal changes in the fuel complex, by modifying fuel mass and moisture distribution in FIRETEC input data. For red-phase simulations, killed trees retained their entire pre-outbreak biomass, but with a reduced canopy fuel moisture of $15 \%$, which falls within the range for recently killed lodgepole pine needles (Jolly et al. 2012). For gray- phase simulations, the canopy biomass of killed trees was "transferred" from crowns to the surface fuel to mimic the fall of dead canopy fuel.

To account for the effects of burning conditions on disturbance interactions, we simulated each combination of mortality level and temporal phase at three different synoptic scale wind velocities: $10 \mathrm{~m} \mathrm{sec}^{-1}, 20 \mathrm{~m} \mathrm{sec}^{-1}$, 


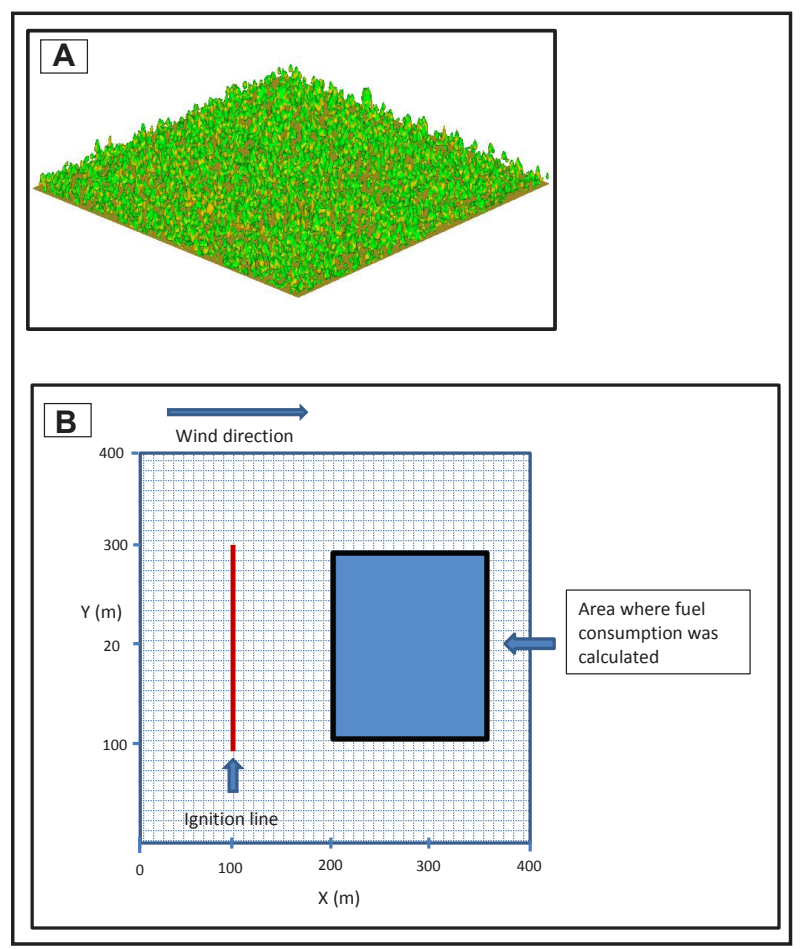

Figure 1. A) no-mortality fuel domain developed from field data showing arrangement of trees; B) top view of the $400 \mathrm{~m} \times 400 \mathrm{~m} \times 450 \mathrm{~m}$ fuel domain, showing ignition line, wind direction, and $178 \mathrm{~m} \times 164 \mathrm{~m}$ area where fuel consumption was calculated.

and $40 \mathrm{~m} \mathrm{sec}^{-1}$, which we refer to as low, moderate, and high, respectively. To develop realistic turbulent wind fields for each simulation, we followed the approach outlined in Pimont et al. (2011) and Cassagne et al. (2011), with a flat topography under neutral atmospheric conditions. We used a 200-meter long fireline 100 $\mathrm{m}$ from the upwind boundary to initiate the fires.

\section{Data Generation and Analyses}

To quantify fire severity, we estimated the fraction of total, live, and dead canopy fuel consumption in a $178 \mathrm{~m} \times 160 \mathrm{~m}$ sampling located $100 \mathrm{~m}$ downwind of the ignition line (Figure 1B) within each simulation. We calculated the fraction of canopy fuel consumption for each $\sim 4 \mathrm{~m}^{2}$ cell by integrating the vertical
Table 2. Summary of the 21 simulations used to model predicted fire behavior in mixed-species ponderosa pine stands. Mortality phases include before a bark beetle attack (green), when the cured needles remain on the trees (red), and when the dead needles have fallen to the ground (gray). Mortality levels were $0 \%$ (green), $20 \%, 58 \%$, and $100 \%$ of ponderosa pine, and synoptic scale wind speeds were $10 \mathrm{~m} \mathrm{sec}^{-1}$ (low), $20 \mathrm{~m} \mathrm{sec}^{-1}$ (moderate), and $40 \mathrm{~m} \mathrm{sec}^{-1}$ (high).

\begin{tabular}{llll}
\hline \multicolumn{1}{c}{ Simulation } & $\begin{array}{c}\text { Mortality } \\
\text { phase }\end{array}$ & $\begin{array}{c}\text { Mortality } \\
\text { level }\end{array}$ & $\begin{array}{c}\text { Wind } \\
\text { speed }\end{array}$ \\
\hline Green_low & green & none & low \\
Green_mod & green & none & moderate \\
Green_high & green & none & high \\
Red20_low & red & $20 \%$ & low \\
Red20_mod & red & $20 \%$ & moderate \\
Red20_high & red & $20 \%$ & high \\
Red58_low & red & $58 \%$ & low \\
Red58_mod & red & $58 \%$ & moderate \\
Red58_high & red & $58 \%$ & high \\
Red100_low & red & $100 \%$ & low \\
Red100_mod & red & $100 \%$ & moderate \\
Red100_high & red & $100 \%$ & high \\
Gray20_low & gray & $20 \%$ & low \\
Gray20_mod & gray & $20 \%$ & moderate \\
Gray20_high & gray & $20 \%$ & high \\
Gray58_low & gray & $58 \%$ & low \\
Gray58_mod & gray & $58 \%$ & moderate \\
Gray58_high & gray & $58 \%$ & high \\
Gray100_low & gray & $100 \%$ & low \\
Gray100_mod & gray & $100 \%$ & moderate \\
Gray100_high & gray & $100 \%$ & high \\
\hline
\end{tabular}

column above each surface cell that had canopy above it and then dividing by the sum of the initial mass in each column. In addition, we qualitatively assessed fire type using definitions in Scott and Reinhardt (2001): surface fire $=$ a fire spreading through surface fuels, torching $=$ a crown fire in which individual or small groups of trees torch out, and active crown fire $=\mathrm{a}$ crown fire in which the entire fuel complex becomes involved.

To compare total fuel consumed across temporal phases, wind speeds, and levels of 
bark beetle-caused mortality severity, we used a spatially blocked bootstrapping approach following Lahiri (2003) and generated 10000 bootstrap samples for each simulation by spatially rearranging trees in the simulation domain. For each bootstrap iteration, we then computed the pairwise differences in mean percent consumption between all pairs of treatment combinations (e.g., low wind green phase versus low wind, low mortality red phase) using Bonferroni-adjusted 95\% confidence intervals to maintain an experiment-wise $\alpha=0.05$ (Dunn 1961). We identified significant differences at $\alpha=0.05$ by adjusted confidence intervals $(\alpha=0.008$ for each phasewind set) for a given difference not including zero. Bootstrap computations and plots were generated using $\mathrm{R}$ version 3.2.0 ( $\mathrm{R}$ development Core Team 2015).

To characterize the type and magnitude of the linkage between the two disturbances (bark beetles and fire), we adapted the approach used by Metz et al. (2013). These authors used the addition theorem of probability, whereby the expected joint fractional mortality of the two agents $=A+(B[1-A])$, where $A=$ fraction of canopy killed by agent $\mathrm{A}$, and $B=$ fraction of canopy killed by agent B. Significant departures above or below this value represented synergistic or antagonistic disturbance interactions, respectively.

We computed canopy mass losses corresponding to each disturbance sequence:

$$
\begin{gathered}
M_{\mathrm{b}}=\frac{m^{\mathrm{d}}}{m_{0}}, \\
M_{\mathrm{f}}=\frac{m_{\mathrm{c}}}{m_{0}}, \\
M_{\mathrm{bf}}=\frac{m^{\mathrm{d}}+m_{\mathrm{c}}^{1}}{m_{0}} .
\end{gathered}
$$

In the above equations, $M_{\mathrm{b}}, M_{\mathrm{f}}$ and $M_{\mathrm{bf}}$ are the mass loss corresponding to beetle mortali- ty alone, fire alone, and fire following beetle mortality, respectively. They are expressed as a fraction of the pre-disturbance canopy fuel mass $m_{\mathrm{o}}$, before either bark beetle-caused mortality or canopy fuel consumption. Variables $m^{\mathrm{d}}$ and $m_{\mathrm{c}}$ are the canopy masses that were killed by bark beetle and consumed by the fire, respectively; $m_{\mathrm{c}}{ }^{1}$ is the canopy fuel mass that survived the beetle attack but was consumed by the fire. The definition of $M_{\mathrm{bf}}$ avoids a double counting of mass losses killed by beetle attack and later consumed by the fire within the canopy at the red stage.

$M_{\mathrm{b}+\mathrm{f}}$ is the mass loss of the fire following bark beetle-caused mortality, assuming independent disturbances (Metz et al. 2013):

$$
M_{\mathrm{b}+\mathrm{f}}=M_{\mathrm{b}}+M_{\mathrm{f}}\left(1-M_{\mathrm{b}}\right) .
$$

We developed a synergism index, Syn, to quantify the magnitude of the linkage between the two disturbances, as the degree of dampening of the second disturbance:

$$
M_{\mathrm{bf}}=M_{\mathrm{b}}+(1+S y n) M_{\mathrm{f}}\left(1-M_{\mathrm{b}}\right)
$$

or, equivalently,

$$
\text { Syn }=\frac{M_{\mathrm{bf}}-M_{\mathrm{b}}}{\left(1-M_{\mathrm{b}}\right) M_{\mathrm{f}}}-1 \text {. }
$$

Combining the above equations leads to:

$$
\text { Syn }=\frac{\frac{m_{\mathrm{C}}^{\mathrm{l}}}{m_{0}-m^{\mathrm{d}}}}{\frac{m_{\mathrm{c}}}{m_{0}}}-1 \text {, }
$$

which expresses that the synergism index is the deviation of the ratios between live fuel consumption in beetle-attacked stands to fuel consumption in unattacked (green-phase) stands.

Syn $=0$ corresponds to disturbances that are neutral or not linked as $M_{\mathrm{bf}}=M_{\mathrm{b}+\mathrm{f}}$ and live fuels consumed in a fire after a beetle attack is similar to the amount consumed by fire in 
green-phase stands. $S y n>0$ corresponds to synergistically linked disturbances. For example, if $S y n=0.5$, the fire severity to the surviving trees would be increased by $50 \%$.

Syn $<0$ corresponds to antagonistically linked disturbances. For example, if $S y n=$ -0.5 , the fire severity to surviving trees would be decreased by $50 \%$.

\section{RESULTS}

\section{Total Canopy Fuel Consumption}

Red phase. Fire severity (the percentage of total canopy fuel consumed) during the red phase increased with the level of mortality compared to the green phase, but the magni- tude of the increase varied by wind speed (Figure $2 \mathrm{~A}, \mathrm{~B}, \mathrm{C}$ ). At low wind speeds, consumption significantly increased with each increase in mortality level (Figure 2A). In the green phase under low winds, the fire was mainly confined to surface fuels with some torching (Figure $3 \mathrm{a}$ ), and only $32 \%$ of the total canopy fuels were consumed. With increasing levels of mortality under low winds, fire severity increased, transitioning to crown fires spreading unimpeded due to the continuity of dry fuel, and consuming twice as much canopy fuel in the $100 \%$ mortality scenario compared to the green phase (Figure $3 \mathrm{j}$ ). In contrast, at moderate and high wind speeds, the magnitude in differences in fuel consumption among mortality levels was small, and only at $\geq 58 \%$ mor-
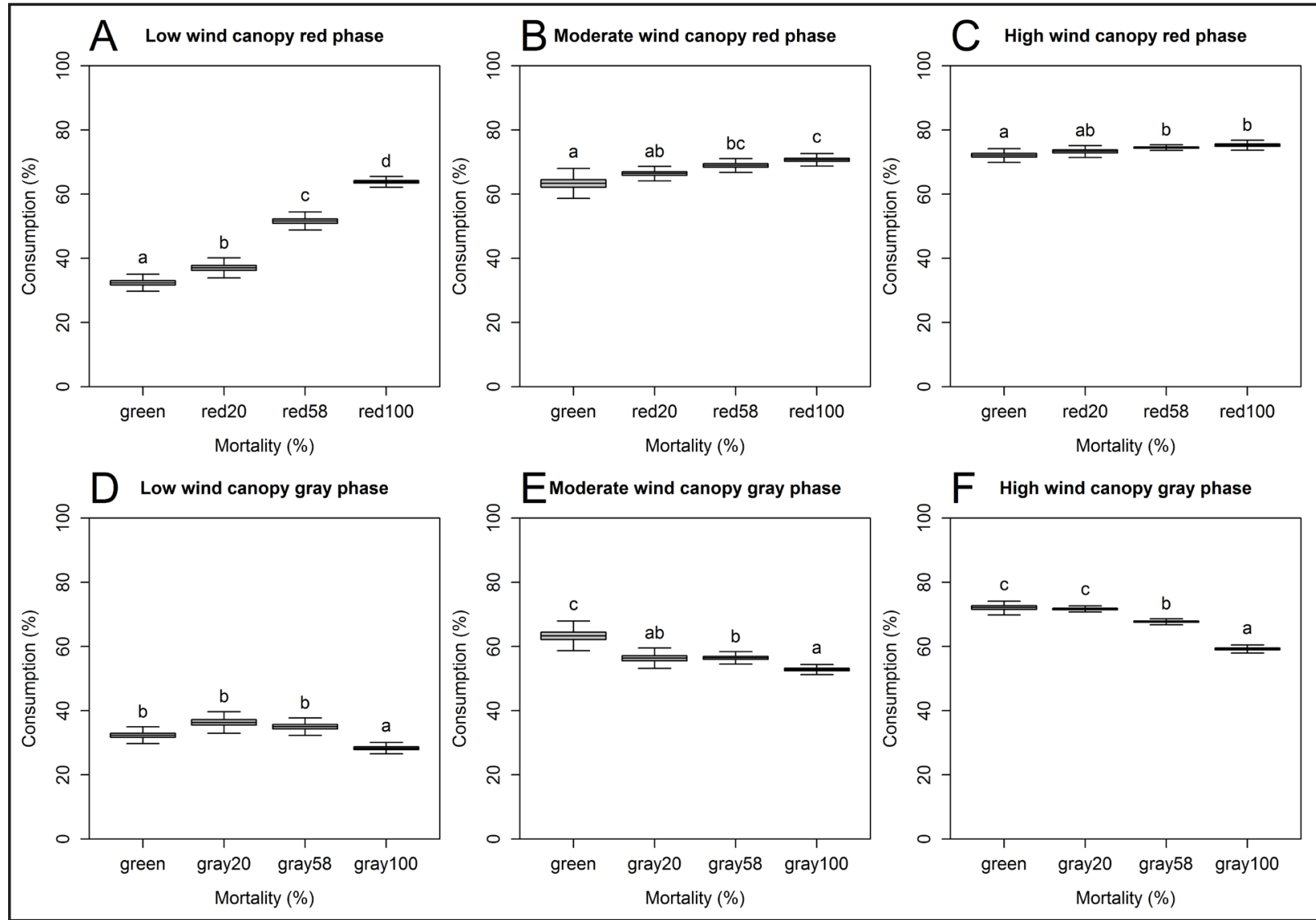

Figure 2. Percent canopy fuel consumption in the red phase (A through $C$ ) and gray phase (D through F), for low $(A, D)$, moderate $(B, E)$, and high wind $(C, F)$ simulations. Boxes indicate $25^{\text {th }}$ and $75^{\text {th }}$ percentiles with medians (solid line); whiskers above and below boxes are calculated as 1.5 multiplied by the interquartile range. Letters above boxes indicate significant Bonferroni-adjusted differences among mortality levels within a given phase-wind speed. 


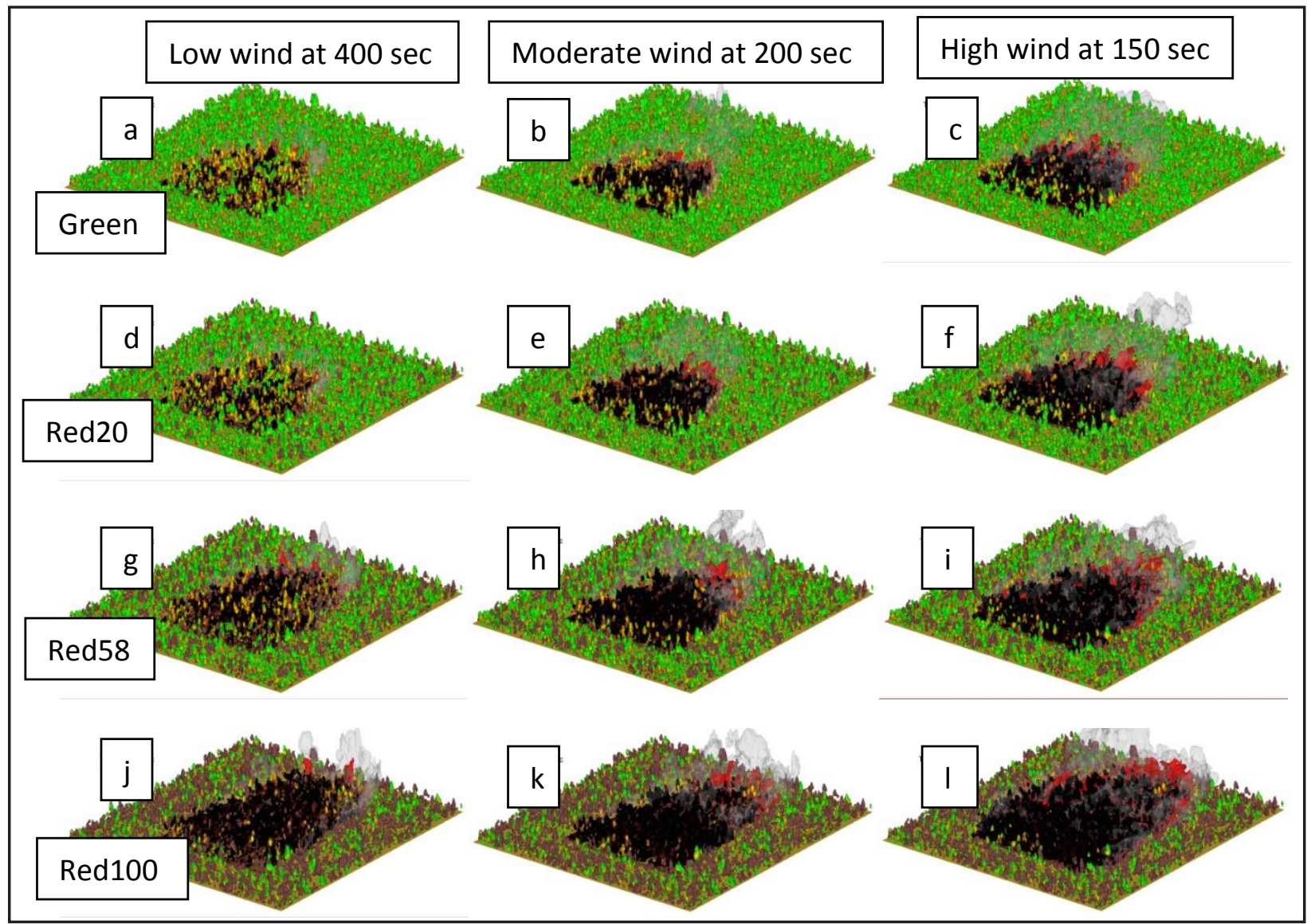

Figure 3. Simulations at $400 \mathrm{~s}$ after ignition for low wind speed (first column), at $200 \mathrm{~s}$ after ignition for moderate wind speed (second column), and at $150 \mathrm{~s}$ for high wind speed (third column). The first row is green phase, second row is red phase $20 \%$ mortality (red20), third row is red phase $58 \%$ mortality (red58), and fourth row is red phase $100 \%$ mortality of all susceptible trees (red100). Colors on the horizontal ground plane indicate the bulk densities of the surface fuels. Live trees are green, dead trees are brown, and burned areas of the canopy are black. The orange, red, and gray isosurfaces indicate areas of hot gases.

tality was canopy fuel consumption significantly higher than in the green phase (Figure $2 \mathrm{~B}, \mathrm{C})$. At moderate wind speed, the fires in all levels of mortality showed crowning behavior and high fuel consumption (Figure 3, second column). Fuel consumption under moderate wind averaged $63 \%$ in green-phase stands, and increased to only $70 \%$ with $100 \%$ ponderosa pine mortality. Consistent with our hypothesis, at high winds, a large proportion ( $72 \%$ to $75 \%$ ) of the canopy burned, regardless of the level of bark beetle-caused tree mortality, and the increases at greater mortality levels were $<4 \%$ (Figure $2 \mathrm{C}$ ). Fires spread easily from tree to tree (active crown fire) un- der high winds, and crowning occurred in all scenarios (Figure 3, third column).

As expected, the percent consumption of canopy fuels was greater for the dead (red phase) than for the live (green-phase) canopy fuels (Figure 4). This was true at all wind speeds, but differences were greater in the low wind speed scenarios. In the $20 \%$ mortality case under low wind conditions, the percent live canopy consumption (31.5\%) was almost equal to that of the green phase $(30.0 \%)$. This would suggest that the presence of torching dead trees did not strongly influence consumption of live fuels. However, dead canopy fuels were consumed nearly twice as much $(62.2 \%)$ 


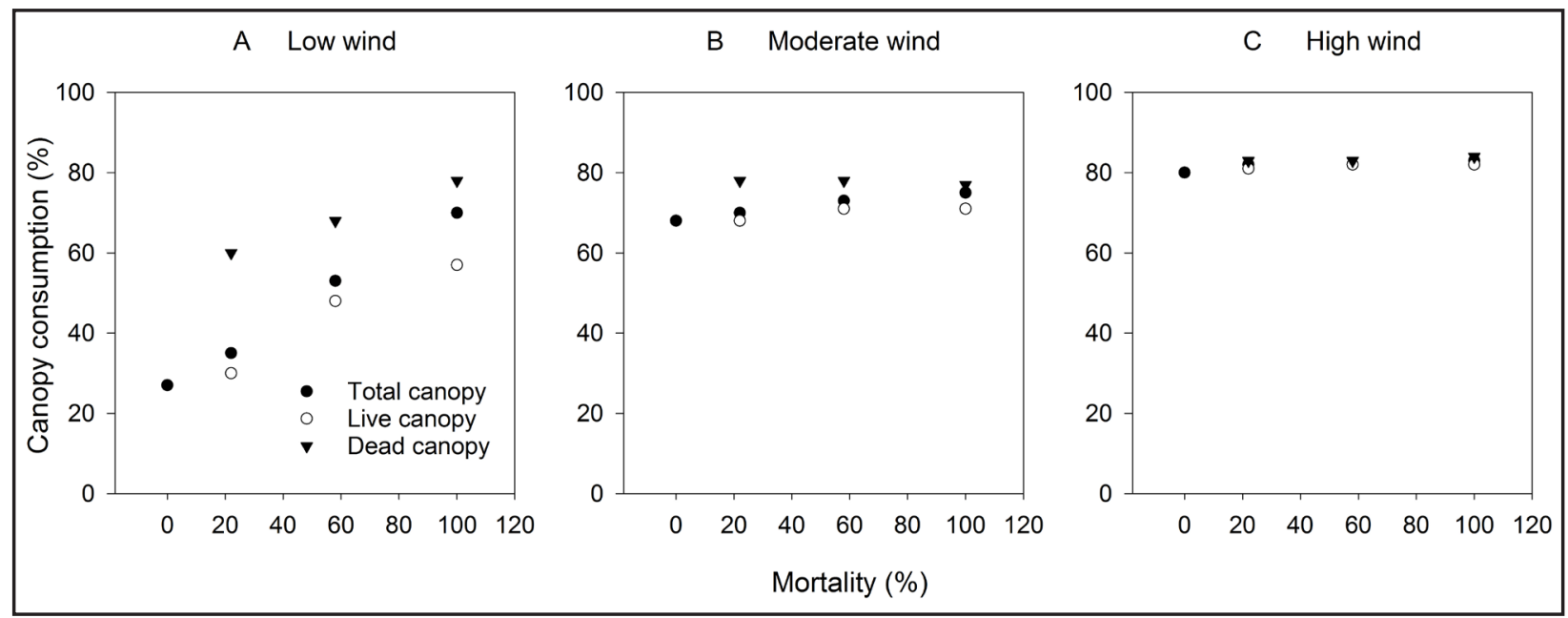

Figure 4. Percentage of live, dead, and total canopy fuel consumed during red-phase fires, by tree mortality level for (A) low, (B) moderate, and (C) high wind speeds.

as the live fuels. At $58 \%$ mortality, percent live fuel consumption $(47.1 \%)$ was noticeably higher than in the green phase $(30.0 \%)$ due to the presence of torching dead trees, but the live fuel consumption was still much lower than dead fuel consumption $(68.6 \%)$. For the $100 \%$ mortality case at low wind speed, the percent live and dead tree consumption was up to $58 \%$ and $73.9 \%$, respectively. As bark beetle-caused mortality increased, and therefore the influence of the burning dead trees increased, burning of the remaining live trees increased as well, suggesting a tendency towards active crown fire instead of the predominantly torching behavior seen at $20 \%$ mortality. We observed similar trends at moderate and high wind speeds, but the magnitude of the differences was smaller at higher wind speeds as the fires consumed more of the total canopy even in the green phase in active crown fires.

Gray phase. In contrast with our hypothesis, at low wind speeds, total canopy fuel consumption did not decrease with increasing levels of mortality until mortality reached $100 \%$. In fact, canopy consumption in the $20 \%$ and $58 \%$ mortality scenarios increased slightly, but not significantly, compared to the green phase (Figure 2D). Under low wind speed, canopy fuel consumption was $36.3 \%$ in the $20 \%$ mortality scenario or $12 \%$ higher than consumption in the green phase. In contrast, with $100 \%$ mortality, post-outbreak total canopy fuel consumed decreased by $12 \%$ compared to the green phase. Fires burning under low wind speeds were characterized by torching and crowning in the green phase, 20\% mortality and 50\% mortality scenarios. At $100 \%$ mortality in the gray phase, surface fire with some torching prevailed (Figure 5, first column).

In contrast to consumption under low winds, under moderate and high winds, there was some support of a pattern of decreasing consumption with increasing mortality levels, but the values were not always significantly lower than consumption in the green phase (Figure 2E, F). Simulated consumption at moderate wind speeds was lower at all levels of mortality $(56.3 \%$ less for $20 \%$ mortality, $56.42 \%$ less for $58 \%$ mortality, and $52.8 \%$ less for $100 \%$ mortality) compared to $63.2 \%$ consumption in the green-phase scenario. Under moderate winds and low mortality, the fire was able to bridge the mortality-caused discontinuities in the crowns to some degree (Figure 5, second column). Under high winds, fires in green phase (Figure 5c) and low-mor- 


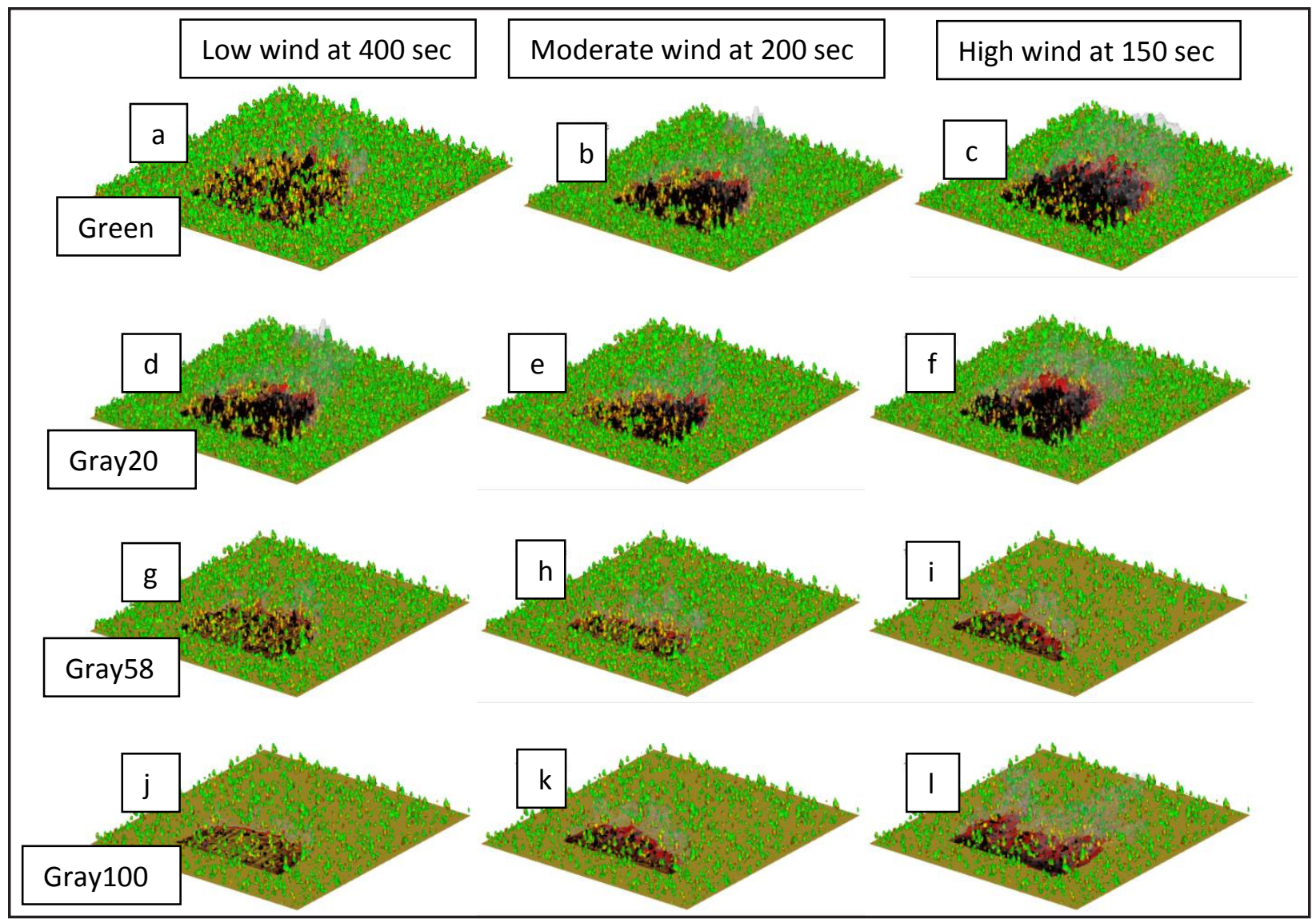

Figure 5. Simulations at $400 \mathrm{~s}$ after ignition for low wind speed (first column), at $200 \mathrm{~s}$ after ignition for moderate wind speed (second column), and at $150 \mathrm{~s}$ for high wind speed (third column). The first row is green phase, second row is gray phase $20 \%$ mortality (gray 20 ), third row is gray phase $58 \%$ mortality (gray58), and fourth row is gray phase $100 \%$ mortality (gray100). Colors on the horizontal ground plane indicate bulk densities of surface fuels. Live tree locations are green, dead tree locations are brown. Burned areas of the canopy are black. The orange, red, and gray isosurfaces indicate areas of hot gases.

tality gray phase (Figure 5f) readily spread from crown to crown; whereas in moderate-mortality (Figure 5i) and high-mortality (Figure 51) gray-phase scenarios, fires spread mostly on the surface. In the high wind scenario, predicted crown consumption averaged $72.1 \%$ in the green-phase scenario, was similar with $20 \%$ mortality $(71.6 \%)$, and decreased monotonically with increasing levels of tree mortality.

\section{Severity Indices and Synergism}

During the red phase, the canopy mass loss from fires following bark beetle attacks $\left(M_{\mathrm{bf}}\right)$ increased with bark beetle-caused mortality levels and wind speed, as did the total fuel consumption as described above (Table 3). More interestingly, $M_{\mathrm{bf}}$ was equal to or greater than $M_{\mathrm{b}+\mathrm{f}}$, meaning that fires during the red phase following bark beetle attacks would result in more severe canopy loss compared to bark beetle attacks and fires occurring independently, leading to a positive synergism index (Table 4). The synergism index reached +0.53 for low wind red phase with $58 \%$ mortality, indicating that the canopy loss was $53 \%$ higher for surviving trees following bark beetle-caused mortality than for green-phase stands, revealing a strong synergy between 
Table 3. Canopy mass loss after bark beetles alone $\left(M_{\mathrm{b}}\right)$, fire alone $\left(M_{\mathrm{f}}\right)$, the combination of bark beetles and fire $\left(M_{\mathrm{bf}}\right)$, and the combination of bark beetles and fire assuming disturbances were independent $\left(M_{\mathrm{b}+\mathrm{f}}\right)$. Phases are green (no mortality), red, and gray with $20 \%, 58 \%$, and $100 \%$ bark beetle-caused mortality of ponderosa pine trees at low $\left(10 \mathrm{~m} \mathrm{sec}^{-1}\right)$, moderate $\left(20 \mathrm{~m} \mathrm{sec}^{-1}\right)$, and high $\left(40 \mathrm{~m} \mathrm{sec}^{-1}\right)$ wind speeds.

\begin{tabular}{|c|c|c|c|c|c|c|c|c|c|c|}
\hline \multirow[b]{2}{*}{ Phase } & \multirow[b]{2}{*}{$M_{\mathrm{b}}$} & \multicolumn{3}{|c|}{ Low wind speed } & \multicolumn{3}{|c|}{ Moderate wind speed } & \multicolumn{3}{|c|}{ High wind speed } \\
\hline & & $M_{\mathrm{f}}$ & $M_{\mathrm{bf}}$ & $M_{\mathrm{b}+\mathrm{f}}$ & $M_{\mathrm{f}}$ & $M_{\mathrm{bf}}$ & $M_{\mathrm{b}+\mathrm{f}}$ & $M_{\mathrm{f}}$ & $M_{\mathrm{bf}}$ & $M_{b+f}$ \\
\hline Green & 0.00 & 0.30 & & & 0.67 & & & 0.82 & & \\
\hline Red20 & 0.14 & & 0.41 & 0.40 & & 0.74 & 0.72 & & 0.85 & 0.84 \\
\hline Red58 & 0.40 & & 0.68 & 0.58 & & 0.85 & 0.80 & & 0.90 & 0.89 \\
\hline Red100 & 0.69 & & 0.87 & 0.79 & & 0.92 & 0.90 & & 0.95 & 0.94 \\
\hline Gray20 & 0.13 & & 0.45 & 0.40 & & 0.63 & 0.72 & & 0.82 & 0.84 \\
\hline Gray58 & 0.39 & & 0.56 & 0.58 & & 0.73 & 0.80 & & 0.85 & 0.89 \\
\hline Gray 100 & 0.72 & & 0.77 & 0.79 & & 0.85 & 0.90 & & 0.88 & 0.94 \\
\hline
\end{tabular}

Table 4. Synergism indices, defined as the factor of increase of canopy mass loss required for the second disturbance agent (here, fire) to reach the same mass loss assuming independence or, equivalently, the deviation of the ratio between mass loss in surviving trees and mass loss in green-phase unattacked stands. If $S y n=0$, the disturbances are neutral $(\mathrm{N})$; values $>0$ indicate synergistic disturbances $(+)$, and values $<0$ indicate antagonistic disturbances $(-)$. Bolded values differ from zero by $>0.05$. Values $<0.05$ are neutral $(\mathrm{N})$; degrees of synergism are denoted as: $(+)$ for values $>0.1,(++)$ for values $>0.2$, and $(+++)$ for values $>0.5$. Degrees of antagonism are denoted as (-) for values $<-0.1,(--)$ for values $<-0.2$, and $(---)$ for values $<-0.5$.

\begin{tabular}{llcc}
\hline Phase & Low wind & Moderate wind & High wind \\
\hline Red20 & $0.0194(\mathrm{~N})$ & $0.0309(\mathrm{~N})$ & $0.0082(\mathrm{~N})$ \\
Red58 & $\mathbf{0 . 5 3 0}(+++)$ & $\mathbf{0 . 0 9 6 8}(+)$ & $0.0230(\mathrm{~N})$ \\
Red100 & $\mathbf{0 . 8 9 0}(+++)$ & $\mathbf{0 . 1 1 7}(+)$ & $0.0212(\mathrm{~N})$ \\
Gray20 & $\mathbf{0 . 2 0 2}(++)$ & $\mathbf{- 0 . 1 3 0}(-)$ & $-0.0165(\mathrm{~N})$ \\
Gray58 & $\mathbf{- 0 . 0 7 9 3 ( - )}$ & $\mathbf{- 0 . 1 6 9 ( - )}$ & $\mathbf{- 0 . 0 7 5 8}(-)$ \\
Gray100 & $-\mathbf{0 . 3 3 8}(--)$ & $\mathbf{- 0 . 2 8 9}(--)$ & $\mathbf{- 0 . 2 6 9}(--)$ \\
\hline
\end{tabular}

bark beetle attacks and fire in this scenario. The synergism was maximum $(+0.89)$ at $100 \%$ bark beetle-caused mortality of ponderosa pine trees and low wind speeds. That is, fires during the red phase following bark beetle-caused mortality would result in an $89 \%$ increase of canopy loss compared to bark beetle-caused mortality and fires occurring independently. We observed similar effects for the moderate wind speed, but the synergism was less pronounced $(10 \%$ to $12 \%)$. At high winds or for the lowest level of mortality (Red20, Table 4), the synergism was negligible, indicating a neutral linkage between the two disturbances in these conditions.
In the gray phase, increasing levels of mortality generally resulted in increasing levels of canopy mass losses at all wind speeds (Table 3 ). Yet, in all cases except the low wind 20\% mortality scenario, the combined effect of bark beetle attack and fire was less severe than the canopy losses when the disturbances occurred independently; that is, $M_{\mathrm{bf}}$ was equal to or less than $M_{\mathrm{b}+\mathrm{f}}$. Thus, all but two of the synergism indices for the gray phase showed antagonistic linkages between bark beetle attacks and fires (Table 4), suggesting that the bark beetlecaused tree mortality tended to decrease the severity of the subsequent fire on surviving trees by $8 \%$ to $34 \%$, especially in stands with 
high mortality rates. The one synergistic effect $\left(M_{\mathrm{bf}}>M_{\mathrm{b}+\mathrm{f}}\right)$ occurred in low mortality scenarios under low wind, in which $45 \%$ of the canopy fuel was consumed following bark beetle attack compared to $40 \%$, assuming the disturbances were independent. In this scenario, the disturbances were synergistic $(+0.202$, Table 4). The one gray-phase scenario with neutral linkage between disturbances was the low mortality level under high wind.

\section{DISCUSSION}

Although bark beetle attacks and fire are common disturbances in forest ecosystems, variability in initial conditions, the temporal phase, severity of bark beetle-caused mortality, and the fire weather can lead to different conclusions about the interaction of these two disturbances (Parker et al. 2006). Our design that controlled for initial conditions and incorporated a full-factorial range of three factors thought to control fire severity following bark beetle mortality provided insights into disturbance interactions and aids in explaining seemingly contrasting results among previous studies. Our work demonstrates the complex influences of bark beetle-caused mortality on the severity of subsequent fires, as well as on the nature and magnitude of interactions between bark beetle attacks and fires. Depending on the temporal phase of the bark beetlecaused mortality and attack severity, as well as fire weather (here, wind), bark beetle-caused mortality may or may not have significant effects on total fuel consumption, and our indices based on canopy loss show that bark beetle attacks and fire may or may not be linked disturbances. Notably, wind speed had a strong influence on the type and magnitude of the interaction between bark beetle attacks and fire, which was expected given the critical role wind speed has regarding crown fire initiation and propagation (Van Wagner 1977). Several previous retrospective studies have approximated burning conditions in bark beetle-im- pacted forests as moderate or severe using temperature and relative humidity ranges, but wind data were not available (e.g., Prichard and Kennedy 2014, Agne et al. 2016). Our results suggest that including ambient wind in burn condition estimates would likely improve our understanding of fire effects in bark beetle-impacted forest fuels.

As we hypothesized, during the red phase, regardless of the amount of bark beetle-caused tree mortality and wind speed, fire severity increased compared to fires in the green phase, and the level of amplification increased with increasing levels of tree mortality. We attributed the increase in fire severity during the red phase to the reduction in fuel moisture content that occurs when needles die. Lower fuel moisture levels during the red phase are critical to alter the threshold required for crown ignition (Jolly et al. 2012, Page et al. 2012, Giunta et al. 2016) and transition from the surface into the canopy. For example, dead red-phase lodgepole pine (Pinus contorta Douglas ex Loudon) needles averaged $\sim 12 \%$ moisture content compared to green needles that averaged $\sim 109 \%$ moisture content; and dead needles ignited up to four times faster than green needles in laboratory ignition tests (Jolly et al. 2012). At low wind speeds and low mortality levels, this effect results in the torching of dead trees, but has only minimal effect on consumption of live trees. At higher mortality levels, the abundance of burning dead trees begins to affect the burning of live trees, and the canopy begins to support some active crown fire activity even at low wind speeds. Simulations in lodgepole pine by Hoffman et al. (2012b) showed a similar increase in canopy fuel consumption, as did observations by Harvey et al. (2014b) in the earliest phases of a bark beetle outbreak in lodgepole pine in Wyoming, USA, and observations by Prichard and Kennedy (2014) following wildfires that burned through red-phase mortality in mixed conifer stands in Washington, USA. Here, we showed that this increase was 
not only due to fuel consumption of dead trees, but also due to fuel consumption of the live trees that survived the bark beetle outbreak, revealing the synergy between the two disturbances. Moderate and high wind speeds created scenarios that were progressively more conducive to crown fire spread even in the green phase, and the reduced fuel moisture was less important. Although the presence of dead foliage in the crowns increased fire severity at higher wind speeds, active crowning also occurred in green-phase stands under these wind speeds and thus the mortality had less influence. The implication is that, under dry conditions and high winds, the presence or even prevalence of red-phase bark beetlecaused tree mortality may have little or no effect on fire severity. These results are in agreement with a retrospective study (Bond et al. 2009) that found no evidence that recent bark beetle-caused mortality influenced fire severity in two wildfires in California, USA, mixed-conifer forests that burned under extreme fire weather caused by Santa Ana winds.

The increase in fire severity and synergism predicted in our study for red-phase stands under low- to moderate-wind speeds appears to contradict the conclusion by Harvey et al. (2014a) that fire severity in lodgepole pine stands was largely unaffected by pre-fire bark beetle-outbreak severity. The differences between the two studies could be because Harvey et al. studied a mid-red-phase lodgepole pine forest, with only $\sim 50 \%$ of the dead needles retained in the canopy, and our study addressed the early red phase, before any of the dead needles had fallen off the trees. In addition, Harvey et al. (2014a) studied mountain pine beetle-caused mortality that resulted in needle loss over multiple years, whereas the abrupt and widespread mortality that we studied in Southwestern ponderosa pine forests was incited by a "global change-type drought" (Breshears et al. 2009) that increased susceptibility to multiple Ips and Dendroctonus bark beetle species, killing trees within one to two years (Negrón et al. 2009). Finally, if the "moderate" and "extreme" burning conditions approximated by Harvey et al. (2014a) by relative humidity and temperature also included higher wind speeds, their results are in line with our simulations that suggested that increasing levels of mortality during the red phase under moderate- and high-wind speeds led to minor and sometimes non-significant increases in fire severity.

In partial support of our hypothesis, the gray-phase simulations suggested that, as dead needles fell to the ground, total canopy consumption generally decreased compared to green-phase scenarios, especially with moderate- or high-wind speeds and mortality levels above $20 \%$. This is in line with the assessment of Meigs et al. (2016) of remotely sensed fire severity in wildfires that burned through gray-phase insect-impacted forests in the Pacific Northwest. That is, after accounting for pre-fire biomass and topography, burn severity was generally lower in forests with higher prefire insect damage (Meigs et al. 2016). However, our simulations revealed one exception, at low levels of mortality and low wind speeds, whereby consumption did not decline until mortality reached $100 \%$ under low winds and $58 \%$ under high winds. We attributed these unexpected results to both the decline in the canopy fuels, which allows greater wind penetration that invigorates the fire, and to the slight increase in surface fuels, which enhanced the sustainability and continuity of the surface fire. Page and Jenkins (2007) speculated that increased wind penetration and increased surface fuels in the gray phase could facilitate surface fires transitioning into crown fires, and these simulations support that. Linn et al. (2012) found that the addition of dead needles during the gray phase provided greater surface fuel continuity, and therefore sustained simulated fire spread in patchy pinyon-juniper woodlands. The study by Hoffman (2011) in lodgepole pine forests found that simulated crown consumption was higher in stands expe- 
riencing between $20 \%$ and $55 \%$ mortality compared to green-phase stands, which they also attributed to the combination of increased wind penetration and surface fuels with adequate levels of crown continuity. Agne et al. (2016) also noted that high-severity fire was more prevalent in lodgepole pine stands with lower levels of mountain pine beetle-caused tree mortality during the gray phase that burned in an Oregon, USA, wildfire. In contrast, Andrus et al. (2016) reported higher firekilled basal area with increasing beetle-killed basal area under moderate burning conditions during the gray phase in Engelmann spruce (Picea engelmannii Parry ex Engelm.)-subalpine fir (Abies lasiocarpa [Hook.] Nutt.) forests affected by spruce beetles (Dendroctonus rufipennis Kirby) in Colorado, USA, but noted that canopy fire is not necessary to kill thinbarked and shallow-rooted spruce and fir trees.

This study addressed a number of knowledge gaps raised in the review by Hicke et al. (2012), as well as several of the limitations of previous studies highlighted in the review by Page et al. (2014). First, our study explored the influence of bark beetle-caused mortality on fire severity in a lesser-studied, drier mixed-species forest type dominated by ponderosa pine, and the role of canopy fuel moisture on fire severity in red-phase stands, especially under less severe weather conditions. In addition, we used a design that ensured that bark beetle-impacted stands were similar to green-phase stands. Questions of how similar bark beetle-impacted stands were to greenphase stands often constrain the implications of observational studies. In response to the suggestion by both Hicke et al. (2012) and Page et al. (2014), we used a model that accounted for the complex spatial arrangement of crown fuels that included a mixture of varying levels of live and dead tree canopy fuels, and accounted for variable fuel moisture content of the affected trees. The fact that the model outputs for bark beetle-impacted lodgepole pine are in agreement with measured fire behavior (Hoffman et al. 2016) provides support for FIRETEC's usefulness in predicting fire dynamics in bark beetle-affected ponderosa pine fuels, but it is important to compare these simulation-based findings to emerging data sets in the future. In addition, bark beetle-caused mortality potentially affects other fire behavior attributes, such as rate of spread (ROS), flame length, and fireline intensity. It is evident from our simulations (see Figures 2 and 4) that bark beetle-caused mortality also effected fire ROS, so this is an area that warrants additional work.

\section{Implications}

Our results suggest that bark beetle and fire disturbances can be linked synergistically or antagonistically, and can also be neutral disturbances and, thus, either dampen, amplify, or have little effect on the ecological consequences, as noted by others (Turner 2010, Turner et al. 2013). Given increasing anthropogenic pressures (e.g., land use changes, human population growth, species introductions) and climate change, increased disturbance frequency, as well as interactions among disturbances, are likely consequences in the future (Seidl et al. 2014, Buma 2015, Foster et al. 2016). Although a relatively small proportion of fires have occurred in beetle-killed fuels in the western US over the last three decades $(0.5 \%$ to $1.3 \%$ ), there are recent examples of fires burning through forests with high levels of beetle-impacted fuels (Hicke et al. 2016). For example, $64 \%$ of the fuels burned in the High Park Fire in northern Colorado had previous bark beetle-caused mortality (Hicke et al. 2016). Further, $29 \%$ of the 277 large ( $>400$ ha) fires in recent decades in the Pacific Northwest had over $10 \%$ previous insect damage (Meigs et al. 2016). Thus, future forest policy and management will require a stronger focus on how multiple disturbances might influence the capacity to sustain forest ecosystem services and carbon stocks (Seidl et al. 2016). 
For some dry coniferous forests, such as those dominated by ponderosa pine and affected by a century of fire exclusion and past management practices, moderate levels of bark beetle-caused tree mortality may assist in moving forest densities closer in line with historical averages (Hoffman et al. 2012a), similar to the benefit of moderately burned areas of wildfires (e.g., Stevens-Rumann et al. 2012). Lower tree densities due to bark beetle-caused mortality is likely to enhance stand resistance to both Ips (Negron et al. 2009) and Dendroctonus beetles, partly due to host depletion (e.g., Temperli et al. 2015), but also due to increased vigor of remaining trees (Fettig et al. 2014). Our simulations suggest that bark beetle-induced mortality can also reduce the severity of subsequent fires. In areas with moderate levels of tree mortality, and especially for fires burning in the gray phase, native bark beetles could buffer rather than exacerbate subsequent fire severity. However, if these stands burn under high wind speeds, regardless of the outbreak phase or level of mortality, very little post-outbreak canopy fuels would remain. This is not surprising since no-mortality stands also support active crown fire with nearly the same overall consumption of canopy mass as the combined beetle-caused mortality and fire under high winds. Thus, fires burning under such high-wind conditions may push this mixed-species ecosystem into one at least temporarily dominated by non-pine sprouting species such as Gambel oak and alligator juniper. Such sprouter-dominated patches would tend to be resilient to subsequent fires, but whether ponderosa pine would eventually reestablish is uncertain (Savage and Mast 2005, Coppoletta et al. 2016).

\section{ACKNOWLEDGEMENTS}

Sources of funding for this research included USDA Forest Service, Forest Health Monitoring, Evaluation Monitoring grant INT-F-07-01, and USDA Forest Service Research (both Rocky Mountain Research Station and Washington office) National Fire Plan Dollars through Interagency Agreements 09-IA-11221633-215 and 13-IA-11221633-103 with Los Alamos National Laboratory and Research Joint Venture Agreement 11-JV-11221633-207 with Colorado State University. Los Alamos National Laboratory's Institutional Computing Program provided computational resources to complete this project. B. Bird, Rocky Mountain Research Statistician; and T. Boivin, INRA-UR629, Ecologie des Forêts Méditerranéennes, provided helpful review comments.

\section{LITERATURE CITED}

Agne, M.C., T. Woolley, and S. Fitzgerald. 2016. Fire severity and cumulative disturbance effects in the post-mountain pine beetle lodgepole pine forests of the Pole Creek Fire. Forest Ecology and Management 366: 73-86. doi: 10.1016/j.foreco.2016.02.004

Andrews, P.L. 2009. BehavePlus fire modeling system, version 5.0: design and features. USDA Forest Service General Technical Report RMRS-GTR-213WWW, Rocky Mountain Research Station, Fort Collins, Colorado, USA.

Andrus, R.A., T.T. Veblen, B.J. Harvey, and S.J. Hart. 2016. Fire severity unaffected by spruce beetle outbreak in spruce-fir forests in southwestern Colorado. Ecological Applications 26: 700-711. doi: 10.1890/15-1121

Bechtold, W.A. 2004. Largest-crown-width prediction models for 53 species in the western United States. Western Journal of Applied Forestry 19: 245-251.

Bentz, B., editor. 2009. Bark beetle outbreaks in western North America: causes and consequences. University of Utah Press, Salt Lake City, USA. 
Bond, M.L., D.E. Lee, C.M. Bradley, and C.T. Hanson. 2009. Influence of pre-fire tree mortality on fire severity in conifer forests of the San Bernardino Mountains, California. The Open Science Journal 2: 41-47. doi: 10.2174/1874398600902010041

Bossert, J.E., R.R. Linn, J.M. Reisner, J.L. Winterkamp, P. Dennison, and D. Roberts. 2000. Coupled atmosphere-fire behavior model sensitivity to spatial fuels characterization. Pages 21-26 in: Third symposium on fire and forest meteorology, 9-14 January 2000, Long Beach, California-preprint volume. American Meteorology Society, Boston, Massachusetts, USA.

Bradley, M. 2002. This model can take the heat. Science and Technology Review. <http:// www.llnl.gov/str/November02/Bradley.html>. Accessed 19 June 2015.

Breshears, D.D., O.B. Myers, C.W. Meyer, F.J. Barnes, C.B. Zou, C.D. Allen, N.G. McDowell, and W.T. Pockman. 2009. Tree die-off in response to global change-type drought: mortality insights from a decade of plant water potential measurements. Frontiers in Ecology and Environment 7(4): 185-189. doi: 10.1890/080016

Buma, B. 2015. Disturbance interactions: characterization, prediction, and the potential for cascading effects. Ecosphere 6: 70. doi: 10.1890/ES15-00058.1

Cassagne, N., F. Pimont, J.-L. Dupuy, R.R. Linn, A. Marrel, C. Olivieri, and R. Rigolot. 2011. Using a fire propagation model to assess the efficiency of prescribed burning in reducing the fire hazard. Ecological Modelling 222: 1502-1514.

Coppoletta, M., K.E. Merriam, B.M. Collins. 2015. Post-fire vegetation and fuel development influences fire severity patterns in reburns. Ecological Applications 26: 686-699. doi: $10.1890 / 15-0225$

Darling, E.S., and I.M. Côté. 2008. Quantifying the evidence for ecological synergies. Ecology Letters 11: 1278-1286. doi: 10.1111/j.1461-0248.2008.01243.x

DeRose, R.J., and J.N. Long. 2009. Wildfire and spruce beetle outbreak: simulation of interacting disturbances in the central Rocky Mountains. Ecoscience 16: 28-38. doi: 10.2980/16-13160

Donato, D.C., B.J. Harvey, W.H. Romme, M. Simard, and M.G. Turner. 2013. Bark beetle effects on fuel profiles across a range of stand structures in Douglas-fir forests of Greater Yellowstone. Ecological Applications 23: 3-20. doi: 10.1890/12-0772.1

Dunn, O.J. 1961. Multiple comparisons among means. Journal of the American Statistical Association 56 (293): 52-64. doi: 10.1080/01621459.1961.10482090

Dupuy. J.-L., R.R. Linn, V. Konovalov, F. Pimont, J.A. Vega, and E. Jimenez. 2011. Exploring coupled fire/atmosphere interactions downwind of wind-driven surface fires and their influence on backfiring using the HIGRAD-FIRETEC model. International Journal of Wildland Fire 20: 734-750. doi: 10.1071/WF10035

Dupuy, J.-L., F.F. Pimont, and R.R. Linn. 2014. FIRETEC evaluation against the FireFlux experiment: preliminary results. Pages 261-274 in: D.X. Viegas, editor. Advances in forest fire research. Chapter 1 - fire behaviour and modelling. Coimbra University Press, Portugal. doi: 10.14195/978-989-26-0884-6_28

Fettig, C.J., K.E. Gibson, A.S. Munson, and J.F. Negrón. 2014. Cultural practices for prevention and mitigation of mountain pine beetle infestations. Forest Science 60(3): 450-463.

Foster, C.N., C.F. Sato, D.B. Lindenmayer, and P.S. Barton. 2016. Integrating theory into disturbance interaction experiments to better inform ecosystem management. Global Change Biology 22: 1325-1335. doi: 10.1111/gcb.13155

Giunta, A.D., M.J. Jenkins, E.G. Hebertson, and A.S. Munson. 2016. Disturbance agents and their associated effects on the health of interior Douglas-fir forests in the central Rocky Mountains. Forests 7(4), 80. doi: 10.3390/f7040080 
Gunderson, L.H. 2000. Ecological resilience - in theory and application. Annual Review of Ecology and Systematics 31: 425-439. doi: 10.1146/annurev.ecolsys.31.1.425

Hart, S.J., T. Schoennagel, T.T. Veblen, and T.B. Chapman. 2015. Area burned in the western United States is unaffected by recent mountain pine beetle outbreaks. Proceedings of the National Academy of Sciences of the USA 112: 4375-4380. doi: 10.1073/pnas.1424037112

Harvey, B.J., D.C. Donato, W.H. Romme, and M.G. Turner. 2013. Influence of recent bark beetle outbreak on fire severity and postfire tree regeneration in montane Douglas-fir forests. Ecology 94: 2475-2486. doi: 10.1890/13-0188.1

Harvey, B.J., D.C. Donato, and M.G. Turner. 2014a. Recent mountain pine beetle outbreaks, wildfire severity, and postfire tree regeneration in the US northern Rockies. Proceedings of the National Academy of Sciences of the USA 111: 15120-15125. doi: 10.1073/ pnas. 1411346111

Harvey, B.J., D.C. Donato, and M.G. Turner. 2014b. Fire severity and tree regeneration following bark beetle outbreaks: the role of outbreak phase and burning conditions. Ecological Applications 24: 1608-1625. doi: 10.1890/13-1851.1

Hicke, J.A., M.C. Johnson, J.L. Hayes, and H.K. Preisler. 2012. Review: effects of bark beetlecaused mortality on wildfire. Forest Ecology and Management 271: 81-90. doi: 10.1016/j. foreco.2012.02.005

Hicke, J.A., A.J.H. Meddens, and C.A. Kolden. 2016. Recent tree mortality in the western United States from bark beetles and forest fires. Forest Science 62: 141-153. doi: 10.5849/forsci. 15-086

Hoffman, C.M. 2011. Numerical simulation of crown fire hazard in bark beetle infested lodgepole pine forests. Dissertation, University of Idaho. Moscow, USA.

Hoffman, C.M., C.H. Sieg, J.D. McMillin, and P.Z. Fulé. 2012a. Fuel loadings 5 years after a bark beetle outbreak in southwestern USA ponderosa pine forests. International Journal of Wildland Fire 21: 306-312. doi: 10.1071/WF11019

Hoffman, C.M., P. Morgan, W. Mell, R. Parsons, E.K. Strand, and S. Cook. 2012b. Numerical simulation of crown fire hazard immediately after bark beetle-caused mortality in lodgepole pine forests. Forest Science 58: 178-188. doi: 10.5849/forsci.10-137

Hoffman, C.M., R. Parsons, R. Linn, C. Sieg, and J. Winterkamp. 2015. Modeling interactions of beetle attacks and fire behavior over time in lodgepole pine stands using FIRETEC. Agricultural and Forest Meteorology 204: 79-93. doi: 10.1016/j.agrformet.2015.01.018

Hoffman, C.M., J. Canfield, R.R. Linn, W. Mell, C.H. Sieg, F. Pimont, and J. Ziegler. 2016. Evaluating crown fire rate of spread predictions from physics-based models. Fire Technology 52: 221-237. doi: 10.1007/s10694-015-0500-3

Jenkins, M.J., E. Hebertson, W.G. Page, and C.A. Jorgensen. 2008. Bark beetles, fuels, fires and implications for forest management in the Intermountain West. Forest Ecology and Management 254: 16-34. doi: 10.1016/j.foreco.2007.09.045

Jenkins, M.J., W.G. Page, E.G. Hebertson, and M.E. Alexander. 2012. Fuels and fire behavior dynamics in bark beetle-attacked forests in western North America and implications for fire management. Forest Ecology and Management 275: 23-34. doi: 10.1016/j.foreco. 2012.02.036

Jenkins, M.J., J.B. Runyon, C.J. Fettig, W.G. Page, and B.J. Bentz. 2014. Interactions among the mountain pine beetle, fires, and fuels. Forest Science 60: 489-501. doi: 10.5849/forsci. 13-017 
Jolly, W.M., R.A. Parsons, A.M. Hadlow, G.M. Cohn, S.S. McAlister, J.B. Popp, R.M. Hubbard, and J.F. Negrón. 2012. Relationships between moisture, chemistry, and ignition of Pinus contorta needles during the early phases of mountain pine beetle attack. Forest Ecology and Management 269: 52-59. doi: 10.1016/j.foreco.2011.12.022

Lahiri, S.N. 2003. Resampling methods for dependent data. Springer Series in statistics. Springer-Verlag, New York, New York, USA. doi: 10.1007/978-1-4757-3803-2

Linn, R.R. 1997. A transport model for prediction of wildfire behavior. Dissertation, New Mexico State University, Las Cruces, USA.

Linn, R.R., J. Reisner, J.J. Colman, and J. Winterkamp. 2002. Studying wildfire behavior using FIRETEC. International Journal of Wildland Fire 11: 233-246. doi: 10.1071/WF02007

Linn, R.R., J. Winterkamp, J. Colman, and C. Edminster. 2005. Modeling interactions between fire and atmosphere in discrete element fuel beds. International Journal of Wildland Fire 14: 37-48. doi: 10.1071/WF04043

Linn, R.R., and P. Cunningham. 2005. Numerical simulations of grass fires using a coupled atmosphere-fire model: basic fire behavior and dependence on wind speed. Journal of Geophysical Research 110: D13107. doi: 10.1029/2004JD005597

Linn, R.R, K. Anderson, J. Winterkamp, A. Brooks, M. Wotton, J.-L. Dupuy, F. Pimont, and C. Edminster. 2012. Incorporating field wind data into FIRETEC simulations of the International Crown Fire Modeling Experiment (ICFME): preliminary lessons learned. Canadian Journal of Forest Research 42(5): 879-898. doi: 10.1139/x2012-038

Linn, R.R., C.H. Sieg, C. M. Hoffman, J. Winterkamp, and J.D. McMillin. 2013. Modeling wind fields and fire propagation following bark beetle outbreaks in spatially-heterogeneous pinyon-juniper woodland fuel complexes. Agriculture and Forest Meteorology 173: 139-153. doi: 10.1016/j.agrformet.2012.11.007

Marino, E., J.-L. Dupuy, F. Pimont, M. Guijarro, C. Hernando, and R.R. Linn. 2012. Fuel bulk density and fuel moisture content effect on fire rate of spread: a comparison between FIRETEC model predictions and experimental results in shrub fuels. Journal of Fire Sciences 30(4): 277-299. doi: 10.1177/0734904111434286

Meigs, G.W., H.S.J. Zald, J.L. Campbel, W.S. Keeton, and R.E. Kennedy. 2016. Do insect outbreaks reduce the severity of subsequent forest fires? Environmental Research Letters 11: 045008. doi: 10.1088/1748-9326/11/4/045008

Metz, M.R., J.M. Varner, K.M. Frangioso, R.K. Meentemeyer, and D.M. Rizzo. 2013. Unexpected redwood mortality from synergies between wildfire and an emerging infectious disease. Ecology 94: 2152-2159. doi: 10.1890/13-0915.1

Negrón, J.F., J.D. McMillin, J.A. Anhold, and D. Coulson. 2009. Bark beetle-caused mortality in a drought-affected ponderosa pine landscape in Arizona, USA. Forest Ecology and Management 257: 1353-1362. doi: 10.1016/j.foreco.2008.12.002

Page, W.G., and M.J. Jenkins. 2007. Predicted fire behavior in selected mountain pine beetle-infested lodgepole pine. Forest Science 53: 662-674.

Page, W.G., M.J. Jenkins, and J.B. Runyon. 2012. Mountain pine beetle attack alters the chemistry and flammability of lodgepole pine foliage. Canadian Journal Forest Research 42: 16311647. doi: 10.1139/x2012-094

Page, W.G., M.J. Jenkins, and M.E. Alexander. 2014. Crown potential in lodgepole pine forests during the red phase of mountain pine beetle attack. Forestry 87: 347-361. doi: 10.1093/ forestry/cpu003 
Parker, T.J., K.M. Clancy, R.L. Mathiasen. 2006. Interactions among fire, insects and pathogens in coniferous forests of the interior western United States and Canada. Agricultural and Forest Entomology 8: 167-189. doi: 10.1111/j.1461-9563.2006.00305.x

Pimont F., J.-L. Dupuy, R.R. Linn, and S. Dupont. 2009. Validation of FIRETEC wind-flows over a canopy and a fuel-break. International Journal of Wildland Fire 18: 775-790. doi: 10.1071/WF07130

Pimont, F., J.-L. Dupuy, R.R. Linn, and S. Dupont. 2011. Impact of tree canopy structure on wind-flows and fire propagation simulated with FIRETEC. Annals Forest Science 68(3): 523-530. doi: 10.1007/s13595-011-0061-7

Pimont, F., J.-L. Dupuy, and R.R. Linn. 2014. Fire effects on the physical environment in the WUI using FIRETEC. Pages 749-757 in: D.X. Viegas, editor. Advances in forest fire research. Chapter 3-fire management. Coimbra University Press, Portugal. doi: 10.14195/978-989-26-0884-6_83

Prichard, S.J., and M.C. Kennedy. 2014. Fuel treatments and landform modify landscape patterns of burn severity in an extreme fire event. Ecological Applications 24(3): 571-590. doi: 10.1890/13-0343.1

R Development Core Team. 2015. R: a language and environment for statistical computing. R Foundation for Statistical Computing, Vienna, Austria.

Ripley, B.D. 1977. Modelling spatial patterns. Journal of the Royal Statistical Society. Series B (Methodological) 39(2): 172-212.

Rothermel, R.W. 1983. How to predict fire spread and intensity of forest and range fires. USDA Forest Service Station General Technical Report INT-143, Intermountain Forest and Range Experiment, Ogden, Utah, USA.

Sabo, K.E., C.H. Sieg, S.C. Hart, and J.D. Bailey. 2009. The role of disturbance severity and canopy closure on standing crop of understory plant species in ponderosa pine stands in northern Arizona, USA. Forest Ecology and Management 257: 1656-1662. doi: 10.1016/j. foreco.2009.01.006

Savage, M., J.N. Mast. 2005. How resilient are Southwestern ponderosa pine forests after crownfire? Canadian Journal of Forest Research 35: 967-977. doi: 10.1139/x05-028

Scott, J.H., and E.D. Reinhardt. 2001. Assessing crown fire potential by linking models of surface and crown fire behavior. USA Forest Service Research Paper RMRS-RP-29, Rocky Mountain Research Station, Fort Collins, Colorado, USA.

Seidl, R., M.-J. Schelhass, W. Rammer, and P.J. Verkerk. 2014. Increasing forest disturbances in Europe and their impact on carbon storage. Nature Climate Change 4: 806-810. doi: $10.1038 /$ nclimate 2318

Seidl, R., T.A. Spies, D.L. Peterson, S.L. Stephens, and J.A. Hicke. 2016. Searching for resilience: addressing the impacts of changing disturbance regimes on forest ecosystem services. Journal of Applied Ecology 53(1): 120-129. doi: 10.1111/1365-2664.12511

Simard, M., W.H. Romme, J.M. Griffin, and M.G. Turner. 2011. Do mountain pine beetle outbreaks change the probability of active crown fire in lodgepole pine forests? Ecological Monographs 81: 3-24. doi: 10.1890/10-1176.1

Stevens-Rumann, C., C.H. Sieg, and M.E. Hunter. 2012. Ten years after wildfires: how does varying tree mortality impact fire hazard and forest resiliency? Forest Ecology and Management 267: 199-208. doi: 10.1016/j.foreco.2011.12.003

Temperli, C., T.T. Veblen, S.J. Hart, D. Kulakowski, and A.J. Tepley. 2015. Interactions among spruce beetle disturbance, climate change and forest dynamics captured by a forest landscape model. Ecosphere 6(11): 231. doi: 10.1890/ES15-00394.1 
Turner, M.G. 2010. Disturbance and landscape dynamics in a changing world. Ecology 91: 2833-2849. doi: 10.1890/10-0097.1

Turner, M.G., and S.P. Bratton. 1987. Fire, grazing, and the landscape heterogeneity of a Georgia barrier reef island. Pages 85-101 in: M.G. Turner, editor. Landscape heterogeneity and disturbance. Springer-Verlag, New York, New York, USA. doi: 10.1007/978-1-4612-474255

Turner, M.G., D.C. Donato, and W.H. Romme. 2013. Consequences of spatial heterogeneity for ecosystem services in changing forest landscapes: priorities for future research. Landscape Ecology 28: 1081-1097. doi: 10.1007/s10980-012-9741-4

USDA Forest Service. 2004. Forest insect and disease conditions in the Southwestern Region. $<$ https://www.fs.usda.gov/Internet/FSE_DOCUMENTS/stelprdb5238440.pdf $>$. Accessed 11 January 2017.

Van Wagner, C.E. 1977. Conditions for the start and spread of crown fire. Canadian Journal of Forest Research 7: 23-34. doi: 10.1139/x77-004

Williams, K., J.D. McMillin, T.E. Gomez, K.M. Clancy, J.A. Anhold, and A. Miller. 2008. Influence of elevation on bark beetle community structure in ponderosa pine stands of north-central Arizona. Environmental Entomology 37: 94-109 doi: 10.1603/0046-225X(2008)37 [94:IOEOBB]2.0.CO;2 